\section{Molecular Support of Rheumatoid Factor and Anti-Gm(a) Activity}

A sPECIFIC serological activity was found several years ago in the serum of patients suffering from rheuma. toid arthritis.

This rheumatoid factor (RAF) has been localized in the 19 S- $\gamma$-globulin ${ }^{1}$. Grubb and Laurell ${ }^{2}$ found a second serological activity in certain arthritis sera (Ragg) causing the agglutination of human red blood cells coated by selected incomplete enti-D sera. This factor has been called anti-Gm activity as it allows the detection of the different $\gamma$-globulin (Gm) groups. The anti-Gm activity is also associated with the $\gamma-19 \mathrm{~S}$ group, so the question arises whether Ragg-serum containing both RAF- and anti-Gm(a) activity has 12 different serologically active populations or whether these activities are associated with the same molecular support.

Steinberg ${ }^{3}$, while studying this problem with the $\mathbf{F}$ II-latex-fixation test, stated that Ragg-serum with both RAF and anti-Gm(a) activity contains two distinct $\gamma$-19 S populations: one with RAF activity alone and the other with both RAF- and anti-Gm(a) activity. Harboe ${ }^{4}$, on the other hand, postulated that Ragg-serum with both serological activities contains two populations: one with RAF activity and the other with anti-Gm(a) activity. These results were obtained by the speoific adsorption of RAF activity on sheop red blood cells coated. with rabbit amboceptor.

While working on the isolation of the molecular support of anti-Gm(a) activity we found that anti-Gm(a) activity from normal serum can be adsorbed specifically on diazotized $p$-aminobenzylcellulose coupled with $\mathrm{Gm}\left(\mathrm{a}^{+}\right)-\gamma$ globulin ${ }^{5}$.

The same support has been found suitable for the dissociation of anti-Gm(a) and RAF activities in Ragg.

The chemical attachment of human $\gamma$-globulin to the insoluble cellulose derivative gives a better reagent than the simple adsorption of the protein on latex particles (polystyrene resin) which is more or less reversible. Pure $\gamma$-globulin of $\mathrm{Gm}\left(\mathrm{a}^{+}\right)$as well as $\mathrm{Gm}(\mathrm{a}-)$ serum has been prepared by a technique combining the precipitation of most of the serum proteins with rivanol and adsorption of the remeining impurities on DEAE cellulose.

The following complexes have been prepared: $(A)$ PAB- $\gamma$ Gm(a $\left(a^{+}\right)$; $(B)$ PAB- $\gamma$ Gm(a-); $(C)$ PAB- $\gamma$ Gm $\left(a_{+}+\right)$, heated; $(D)$ PAB- $\gamma \mathrm{Gm}(\mathrm{a}-)$, heated. In the case of the heated preparations, the solution of $\gamma$-globulin ( 1 per cent) was heated for $10 \mathrm{~min}$ to $63^{\circ} \mathrm{C}$ before combination with the diazotized PAB-cellulose.

The unspecific adsorption of RAF on heat-aggregated $\gamma$-globulin is a well-known phenomenon. Initially we supposed that anti-Gm(a) activity would only be adsorbed by complex $(A)$ and eventually by complex $(C)$, whereas RAF would be adsorbed by $(C)$ and $(D)$.

However, we soon realized that these complexes have a considerable non-specific affinity for both activities. We therefore enquired whether there exists an important quantitative difference between the specific and the nonspecific adsorption of anti-Gm(a) activity by adsorbing different Ragg sera with complexes $(A)$ and $(B)$. Under optimal conditions, using a minimal amount of complex, about 90-100 per cent of anti-Gm(a) will be adsorbed to complex $(A)$, and less than 10 per cent to complex $(B)$, the latter being used as a control to evaluate 'nonspecific adsorption'. Such small differences cannot be detected by ordinary serological techniques and we had to do this quantitation by photometric titration ${ }^{6}$. It was evident that the non-specific adsorption of anti-Gm(a) to PAB- $\gamma-\operatorname{Gm}\left(a_{-}\right)$could be very small (less than 10 per cent) under appropriate conditions.

However, the titration of RAF activity in the supernatant of complex $(A)$ showed a loss of about 25 per cent. It is conceivable that RAF has a greater non-specific affinity for the cellulose-protein complexes than have the
anti-Gm molecules, and the loss of 25 per cent of its activity could be explained by non-specific adsorption. However, complex $(B)$, which adsorbed about 10 per cent of anti-Gm(a) activity (non-specific) did not modify the titre of RAF activity. It is therefore probable that the part of RAF adsorbed together with the total activity of anti-Gm(a) shares a common molecular basis with anti$\mathrm{Gm}(\mathrm{B})$ and that its adsorption is mediated by the specific adsorption of anti-Gm(a) to PAB-Gm( $\left.a^{+}\right)$. The observations therefore suggest that there are two different populations, one of which has both activities, whereas the other has RAF activity alone, as 75 per cent of RAF remains in the adsorbed serum. We found that anti-Gm(a) has a greater affinity (non-specific adsorption) for all the complexes used, so it was not possible to use this system for the adsorption of RAF leaving anti-Gm(a) in the supernatant.

Evidence of a third population, with anti-Gm(a) activity alone, was provided by the adsorption of RAF activity on human red cells sensitized by rabbit amboceptor. Using the photoelectric titration method we found that 50 per cent of anti-Gm(a) activity disappears together with all the R.AF activity.

The concomitant adsorption of 50 per cent of the antiGm(a) activity, however, was not due to non-specific adsorption. Indeed, the serum devoid of RAF activity and of 50 per cent of anti-Gm(a) activity after this first adsorption has been readsorbed by an identical quantity of sensitized red cells and the anti-Gm(a) titre was unchanged (50 per cent of the original titre) after the second adsorption. These observations thus revealed two populations: one having RAF activity as well as antiGm(a) activity, the second heving anti-Gm(a) activity alone. Different Ragg-sera submitted to both tests gave similar results. The exact quantitation for one of our sera revealed that 25 per cent of the RAF activity had a common basis with about 50 per cent of anti-Gm(a) activity whereas 75 per cent of RAF and 50 per cent of anti-Gm-activity hed an independent molecular support. Further details will be published elsewhere.

\section{Steringuch \\ CL. MatTe \\ R. Audran \\ J. Moullec}

Centre National de Transfusion Sanguine, 6 rue Alexandre-Cabanel, Paris.

${ }^{1}$ Kunkel, H. G., Franklin, E. C., and Muller-Eberhard, H. J., J. Clin. Invest., 38, $424(1959)$.

\& Grubb, R., and Laurell, A. B., Acta Path. Microbiol. Scandinav., 39, 390 (1956).

steinberg, A. G., Arthritis and Rheum., 5, 381 (1962).

4 Harboe, H., Tenth Congr. Liga Intern. Rheumatism, Rome, 1961, 282 (Minerva Medica, Torino, 1961).

s Audran, R., Steinbuch, M., and Moullec, J., Proc. Ninth Congr. Intern. Transf., Mexico, 1962, 451 (Karger, Basel, Niew York, 1964). 'Matte, C., Transfusion, Paris, 6, 381 (1963).

\section{Apparent Interaction Between the $\mathbf{X g}^{\mathbf{n}}$ Blood Group System and the Sex Ratio: A Note of Explanation}

Prof. J. H. Bennett has called to our attention a possible source of confusion in our recent letter ${ }^{1}$. We left implicit the assumption that the expected sex-ratios in the two classes, 'Before and including the first female', and 'After the first female', were equal, and we failed to make clear that the numbers of children in our Table 1 included those from all-male sibships. If such sibships had been omitted, the sex ratio (male: female) would indeed have been expected to be higher in the first class than in the second, but when they are included, as was done, the expected ratios are equal. Other explanations of our 